\title{
Physiological and Pathological Roles of CaMKII-PP1 Signaling in the Brain
}

\author{
Norifumi Shioda ${ }^{1, *}$ and Kohji Fukunaga ${ }^{2, *}$ \\ 1 Department of Biofunctional Analysis Laboratory of Molecular Biology, Gifu Pharmaceutical University, \\ 1-25-4 daigaku-nishi, Gifu 501-1196, Japan \\ 2 Department of Pharmacology, Graduate School of Pharmaceutical Sciences, Tohoku University, \\ 6-3 Aramaki-Aoba, Aoba-ku, Sendai, Miyagi 980-8578, Japan \\ * Correspondence: shioda@gifu-pu.ac.jp (N.S.); kfukunaga@m.tohoku.ac.jp (K.F.); \\ Tel.: +81-58-230-8100 (N.S.); +81-22-795-6836 (K.F.); Fax: +81-58-230-8105 (N.S.); +81-22-795-6835 (K.F.)
}

Received: 23 November 2017; Accepted: 20 December 2017; Published: 22 December 2017

\begin{abstract}
Ca}^{2+} /$ calmodulin (CaM)-dependent protein kinase II (CaMKII), a multifunctional serine (Ser)/threonine (Thr) protein kinase, regulates diverse activities related to $\mathrm{Ca}^{2+}$-mediated neuronal plasticity in the brain, including synaptic activity and gene expression. Among its regulators, protein phosphatase-1 (PP1), a Ser/Thr phosphatase, appears to be critical in controlling CaMKII-dependent neuronal signaling. In postsynaptic densities (PSDs), CaMKII is required for hippocampal long-term potentiation (LTP), a cellular process correlated with learning and memory. In response to $\mathrm{Ca}^{2+}$ elevation during hippocampal LTP induction, CaMKII $\alpha$, an isoform that translocates from the cytosol to PSDs, is activated through autophosphorylation at Thr286, generating autonomous kinase activity and a prolonged $\mathrm{Ca}^{2+} / \mathrm{CaM}$-bound state. Moreover, PP1 inhibition enhances Thr286 autophosphorylation of CaMKII $\alpha$ during LTP induction. By contrast, CaMKII nuclear import is regulated by Ser332 phosphorylation state. CaMKII 83 , a nuclear isoform, is dephosphorylated at Ser332 by PP1, promoting its nuclear translocation, where it regulates transcription. In this review, we summarize physio-pathological roles of CaMKII/PP1 signaling in neurons. CaMKII and PP1 crosstalk and regulation of gene expression is important for neuronal plasticity as well as survival and/or differentiation.
\end{abstract}

Keywords: $\mathrm{Ca}^{2+} /$ calmodulin-dependent protein kinase II; protein phosphatase-1; synaptic plasticity; nuclear translocation

\section{Introduction}

Protein phosphorylation, one of the most important post-translational modifications, drives rapid, reversible and extracellular signal-dependent cell signaling. In the brain, $\mathrm{Ca}^{2+} /$ calmodulin (CaM)-dependent protein kinase II (CaMKII), a multifunctional serine (Ser) and threonine (Thr) kinase [1], regulates diverse $\mathrm{Ca}^{2+}$-mediated neuronal activities, including neurotransmitter release, gene expression, and synaptic plasticity [2,3]. CaMKII is a dodecameric holoenzyme assembled from $\alpha, \beta, \gamma$, and $\delta$ isoforms. In eukaryotes, these four CaMKII isoforms are encoded by distinct genes, and their corresponding mRNAs are alternatively spliced to give rise to subtypes exhibiting variable domains $[4,5]$.

CaMKII has attracted substantial attention due to its function in synaptic plasticity, an activity that occurs at postsynaptic densities (PSDs) [6-8]. In response to $\mathrm{Ca}^{2+}$ elevation by extracellular stimuli, $\mathrm{Ca}^{2+}$-CaM binding to CaMKII displaces autoinhibitory domains to allow ATP and exogenous substrates access to the active site. Immediately after activation, Thr286 in the autoinhibitory domain of the $\alpha$ isoform (corresponding to Thr287 of $\beta, \gamma$, and $\delta$ isoforms) is autophosphorylated by the neighboring kinase domain. This event increases $\mathrm{Ca}^{2+}-\mathrm{CaM}$ binding affinity and blocks 
interaction of autoinhibitory and catalytic domains, thereby generating autonomous kinase activity and prolonging the $\mathrm{Ca}^{2+} / \mathrm{CaM}$-bound state. CaMKII $\alpha$ autonomy is critical for induction and maintenance of hippocampal long-term potentiation (LTP), both of which underlie learning and memory $[9,10]$.

The 12 subunits of the CaMKII holoenzyme assemble into two coplanar rings, each containing six subunits [11]. These ring structures suggest a potential mechanism for establishment of an autonomous kinase state, as it is proposed that autophosphorylation occurs by an inter-subunit process [12]. Indeed, following a robust and long $\mathrm{Ca}^{2+}$ stimulus, two adjacent CaMKII monomers are simultaneously bound by $\mathrm{Ca}^{2+} / \mathrm{CaM}$. In these conditions, one subunit serves as a substrate for the other, resulting in Thr286/Thr287 phosphorylation. Once the first subunit is phosphorylated, subsequent phosphorylation within the holoenzyme is more likely to occur, as lower $\mathrm{Ca}^{2+}$ levels are required for the second phosphorylation. Thus, in this scenario, CaMKII remains active, even when $\mathrm{Ca}^{2+}$ levels return to basal levels, until it is dephosphorylated. If the number of phosphorylated subunits exceeds a threshold and the phosphorylation rate is greater than the dephosphorylation rate, then CaMKII activity is sustained [13].

In contrast to postsynaptic CaMKII function, the physiological relevance of nuclear activity of CaMKII isoforms in the central nervous system (CNS) remains unclear. Alternative splicing of CaMKII generates a multitude of isoforms for each CaMKII subunit [5]. Among these alternatively

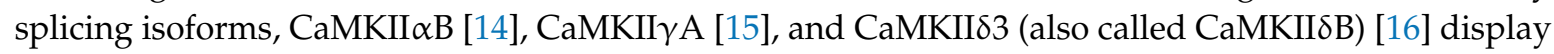
consensus (KKRK) sequences in respective variable domains that resemble a nuclear localization signal (NLS) and are homologous to the simian virus 40 (SV40) large T antigen NLS [17]. In rat brain neurons, CaMKII $\alpha$ B and CaMKII $\delta 3$ are expressed in the nucleus [14,18], and their activity is reportedly regulated by the NLS motif, which, when phosphorylated, prevents nuclear localization. CaMKIII3 Ser332, which is immediately C-terminal to the NLS $\left({ }^{328} \mathrm{KKRKS}{ }^{332}\right)$, is reportedly phosphorylated by the CaMK family members CaMKI or CaMKIV, blocking association of CaMKII with the NLS receptor m-pendulin and thereby preventing nuclear localization [19].

The Ser/Thr phosphatase Protein Phosphatase-1 (PP1), a key regulator of CaMKII signaling, forms a heterodimer comprised of a catalytic (PP1c) and a regulatory subunit. PP1c can form a complex with over 50 regulatory or scaffolding proteins that dictate substrate specificity and subcellular localization [20]. In mammalian cells, PP1c itself occurs as different isoforms $(\alpha, \beta, \delta, \gamma 1$ and $\gamma 2)$ [21-25], and three (PP1 $\alpha, P P 1 \beta$, and PP1 $\gamma 1)$ are highly expressed in the brain [26]. All isoforms show nearly $90 \%$ amino acid homology and are most divergent at the $\mathrm{N}$ - and C-termini. Importantly, although CaMKII $\alpha$ Thr286 can be dephosphorylated by PP1, PP1 appears to play a more prominent role in CaMKII dephosphorylation at PSDs [27]. Moreover, CaMKII 83 is dephosphorylated at Ser332 by PP1, promoting its nuclear translocation [28].

In this review, we focus on the role of CaMKII/PP1 signaling in both neuronal plasticity at PSDs and gene expression in the nuclei. We also discuss how imbalanced CaMKII/PP1 activity may underlie neuronal pathologies, such as mental disorders and neurodegeneration.

\section{Physiological Function of CaMKII/PP1 Signaling at PSDs}

PSDs are localized in the tips of dendritic spine heads and contain multiple classes of proteins that function in neuronal signaling in response to presynaptic neurotransmitter release, such as glutamate [29]. CaMKII is one of the most abundant proteins found in forebrain PSDs [30]. CaMKII regulates synaptic strength, in part by phosphorylating glutamate receptors [31]. As noted, CaMKII $\alpha$ Thr286 autophosphorylation promotes autonomous kinase activity, which when sustained is essential for learning and memory $[9,10]$. Thus, it is critical to understand how CaMKII remains highly phosphorylated and resists endogenous phosphatase activity.

One factor governing this persistent "on-state" is PP1 localization to dendritic spines and PSDs [32,33]. PP1 inhibition enhances CaMKII $\alpha$ Thr286 autophosphorylation during LTP induction [34]. However, autophosphorylated CaMKII $\alpha$ Thr286 cannot be dephosphorylated by PP1 in purified PSDs from rats [35]. These authors also showed that the Thr286 site is not buried 
within the CaMKII $\alpha$ protein, as it can be dephosphorylated in purified PSDs by exogenous soluble PP1c or $\lambda$ phosphatase. These results indicate that the inability of PP1 to dephosphorylate this site in vivo is due to the positioning of PP1 in PSDs and the inhibitory activity of scaffolding proteins that modulate PP1 activity $[36,37]$. For example, spinophilin and its homolog neurabin are F-actin binding proteins that target PP1 to PSDs, and spinophilin alters PP1 catalytic activity by steric inhibition of substrate binding sites [38]. Indeed, numerous protein-protein interactions hold PP1 in such a position that PP1 simply cannot reach CaMKII $\alpha$ Thr286.

Once activated, CaMKII remains in an active conformation throughout the LTP maintenance phase, an observation that forms the basis of the hypothesis that CaMKII is critical for memory formation $[9,10]$. However, these conclusions are based on work carried out using hippocampal homogenates, and these studies do not provide specific information relevant to the pool of active CaMKII at synapses. Some studies using Camui, a fluorescence resonance energy transfer (FRET)-based CaMKII sensor [39], show that CaMKII activity lasts only $\sim 1$ min after stimulation during LTP induction, based on two-photon laser-mediated photolysis of caged glutamate at hippocampal CA1 spines $[40,41]$. CaMKII activity, as measured by the magnitude of the Camui-FRET change, was not affected by treatment with Calyculin A, a PP1/PP2A phosphatase inhibitor [41]. Thus, optical monitoring of CaMKII activity has the advantage of greater spatiotemporal resolution over previous immunoblotting studies. However, they still have technical limitations relating to their ability to detect small amounts of activated CaMKII within dendritic spines. Thus, the relationship between LTP and CaMKII/PP1 signaling needs further investigation.

\section{Pathological CaMKII/PP1 Signaling in PSDs}

In animal models of Parkinson's disease, striatal dopamine depletion increases CaMKII $\alpha$ autophosphorylation at Thr286 in parallel with decreased PP1 $\gamma 1$ activity and increased PP1 $\gamma 1$ binding to spinophilin [42-44]. Moreover, we showed increased CaMKII $\alpha$ Thr286 autophosphorylation and decreased levels of spinophilin and PP1 in the prefrontal cortex of a mouse model of $\alpha$-thalassemia X-linked mental retardation (ATR-X) syndrome [45]. This pathological imbalance of CaMKII/PP1 signaling in the ATR-X model correlated with altered dendritic spine morphology, suggesting that CaMKII/PP1 signaling regulates this process [45]. Likewise, decreased PP1 activity in the brain of Angelman syndrome model mice correlated with increased phosphorylation of hippocampal CaMKII $\alpha$ at Thr286 in PSDs, as well as with changes in synaptic plasticity, learning, and memory [46]. This evidence suggests overall that increased CaMKII activity is mediated by reduced PP1 activity, particularly in PSDs, thereby perturbing synaptic plasticity and learning and memory.

\section{Physiological CaMKII/PP1 Signaling in Nuclei}

Transduction of signals from synapses to the nucleus is primarily mediated by $\mathrm{Ca}^{2+}$ signaling, and nuclear $\mathrm{Ca}^{2+}$ transients are some of the most potent regulators of neuronal gene expression [47]. Nuclear CaMKII transcriptionally regulates the gene encoding neurotrophin brain-derived neurotrophic factor (BDNF) [48,49] through phosphorylation of diverse nuclear proteins, including cAMP response element-binding protein (CREB) [50,51], methyl CpG binding protein 2 (MeCP2) [52], activating transcription factor [53,54], CCAAT/enhancer-binding protein [55,56], and serum response factor [57].

Specifically, CaMKII phosphorylates CREB at Ser133 and Ser142 in vitro [51]. Moreover, $\mathrm{Ca}^{2+}$-induced CaMKII activation in primary cultured neurons stimulates CREB phosphorylation at Sers 133, 142, and 143 [58]. CREB phosphorylation at Ser142 and Ser143 contributes to its activation, and alanine mutations at Ser142 and Ser143 block $\mathrm{Ca}^{2+}$-induced CREB-dependent transcription [58]. However, transgenic mice harboring a single CREB Ser142-to-alanine mutation show alterations in the circadian clock located in the suprachiasmatic nucleus, which down-regulate c-Fos, a transcriptional target of CREB [59]. The transcription factor MeCP2 binds to methylated cytosine residues of $\mathrm{CpG}$ dinucleotides in DNA [60]. Neuronal activity and subsequent $\mathrm{Ca}^{2+}$ influx trigger CaMKII-dependent 
MeCP2 phosphorylation at Ser421 [52]. Knock-in mice that lack MeCP2 Ser421 or Ser421 and Ser424, a second site of synaptic activity-induced phosphorylation, show perturbed synaptogenesis, synaptic plasticity, and spatial memory [61,62], underscoring the importance of these phosphorylation sites in vivo.

Until recently, mechanisms underlying substrate phosphorylation by nuclear CaMKII remained unclear. Thus, we investigated nuclear-cytoplasmic shuttling of the nuclear isoform CaMKII $\delta 3$. Previously, others had reported that CaMKII $\delta 3$ Ser332, which is C-terminal to the NLS $\left({ }^{328} \mathrm{KKRKS}^{332}\right)$, is phosphorylated by CaMKI or CaMKIV, prohibiting nuclear localization [19]. To investigate a potential function of CaMKII phosphorylation, we generated a specific antibody against phosphorylated Ser332 of CaMKII. In an in vitro phosphorylation assay of purified rat brain CaMKII, CaMKIII3 was dephosphorylated by PP1 at both Ser332 and Thr287 [28]. We also showed that PP1 $\alpha$ and PP1 $\gamma 1$ predominantly regulate CaMKII 83 nuclear translocation in Neuro-2a cells. However, nuclear CaMKII $\delta 3$ activity in Neuro-2a cells was enhanced by PP1 $\gamma 1$ overexpression. Consistent with these results, in experiments using primary cultured mesencephalic dopamine neurons, CaMKII $\delta 3$ was dephosphorylated only at Ser332, not at Thr287, by activated PP1 [28]. This discrepancy may be explained by the binding of various proteins to the CaMKII/PP1 complex, in a manner similar to spinophilin in PSDs. We conclude that the in vitro experimental conditions used in our study resemble the cytosolic microenvironment, in which PP1 directly dephosphorylates cytosolic CaMKII $\delta 3$. We have not yet defined proteins binding to and regulating the CaMKII $83 / \mathrm{PP} 1$ complex in vivo, an analysis that awaits future studies.

Others have reported nuclear activity of CaMKII $\alpha \mathrm{B}$ and CaMKII $\gamma \mathrm{A}$ in neurons $[63,64]$. For example, in rat retinal ganglion cells $\mathrm{CaMKII} \alpha \mathrm{B}$ expression and nuclear translocation increase via an unknown mechanism following glutamate-induced cell death [63]. Ma et al. also reported that CaMKII $\gamma \mathrm{A}$ functions as a transporter of $\mathrm{Ca}^{2+} / \mathrm{CaM}$ to the nucleus following depolarization of cultured superior cervical ganglion neurons and that the $\mathrm{Ca}^{2+} / \mathrm{CaM}-\mathrm{CaMKII} \gamma$ complex is dephosphorylated at Ser334 by calcineurin, allowing it to shuttle to the nucleus. Nuclear delivery of $\mathrm{Ca}^{2+} / \mathrm{CaM}$ activates nuclear CaM kinases, including CaMKIV and CaMKK, driving CREB phosphorylation and transcription of its target genes [64]. Therefore, phosphatases other than PP1, such as calcineurin and/or PP2A, may dephosphorylate Ser332 of CaMKII 83 in other types of neurons.

\section{Pathological CaMKII/PP1 Signaling in Nuclei}

CaMKII-PP1 signaling transcriptionally regulates BDNF, a factor vital for neuronal survival, growth, and maintenance, in brain circuits functioning in emotion and cognition [65]. MeCP2 mutations cause most cases of Rett syndrome, an X-linked dominant neurodevelopmental disorder and a leading cause of mental retardation and autistic behavior in females [66]. Phenotypes, such as normal early development followed by progressive motor and cognitive dysfunction, seen in mice that either lack or overexpress MeCP2 recapitulate many characteristic features of Rett syndrome [67-69]. In addition, like syndrome patients, MeCP2 mutant mice show abnormalities in brain morphology and cyto-architecture, in particular a decrease in dendritic arborization and spine loss [52,70]. Importantly, MeCP2 Ser421 phosphorylation by CaMKII is required for activity-dependent regulation of BDNF gene expression [52], suggesting that transcriptional deregulation of this gene potentially due to CaMKII dysregulation plays a central role in Rett syndrome.

We also previously revealed that nuclear CaMKII/PP1 signaling is important for neuronal survival and differentiation [28]. We reported that the nuclear isoform CaMKII $\delta 3$ is highly expressed in dopaminergic rat substantia nigra neurons [71] and that stimulation of the dopamine D2 receptor (D2R) activates CaMKII83, inducing BDNF gene expression in NG108-15 cells [72]. We also found that CaMKII $\delta 3$ Ser332 is directly dephosphorylated by PP1, promoting CaMKII $\delta 3$ nuclear translocation, and that aripiprazole (APZ), a dopamine D2R partial agonist, promotes CaMKII $\delta 3$ nuclear translocation and enhances BDNF expression [28]. APZ treatment also enhanced sprouting and survival of cultured dopaminergic neurons through the CaMKII83/PP1 pathway [28]. Consistent with our 
results, APZ treatment for eight weeks was reported to significantly increase plasma BDNF levels in first-episode untreated schizophrenia patients [73]. BDNF protein expression decreases in the dopamine-deficient substantia nigra of Parkinson disease patients [74,75]. BDNF also reportedly promotes survival of cultured mesencephalic dopaminergic neurons [76] and, in vivo, protects dopaminergic neurons from damage by the neurotoxins 1-methyl-1,2,3,6-tetrahydropiridine and 6-hydroxydopamine [77]. This evidence and our data suggest a critical role for BDNF in supporting survival and/or differentiation of midbrain dopaminergic neurons functioning nuclear CaMKII/PP1 pathway with the APZ treatment.

\section{Conclusions}

CaMKII/PP1 signaling plays a crucial role in many different aspects of synaptic plasticity in PSDs and in activity-regulated transcription in nuclei. CaMKII alternative splicing generates numerous subtypes of each CaMKII isoform. Figure 1 summarizes how each function, in relationship to others, mediates $\mathrm{Ca}^{2+}$ signaling to PSDs or nuclei. However, the composition of the dodecameric CaMKII holoenzyme affects CaMKII localization [78,79]. The ability of CaMKII to translocate to the nucleus is thus governed by the presence of nuclear versus cytoplasmic isoforms that make up holoenzyme [17]. Nuclear CaMKII isoforms containing an NLS (CaMKII $\alpha$ B, CaMKII $\delta 3$, and CaMKII $\gamma \mathrm{A}$ ) may co-assemble with cytoplasmic subunits, including postsynaptic density-associated CaMKII $\alpha$ [80] and/or F-actin-associated CaMKII $\beta$ [81] to facilitate synaptic activation or nuclear translocation. Further study is required to reveal the relationship between oligomerization of heterogenous CaMKII isoforms and PP1 in neurons.

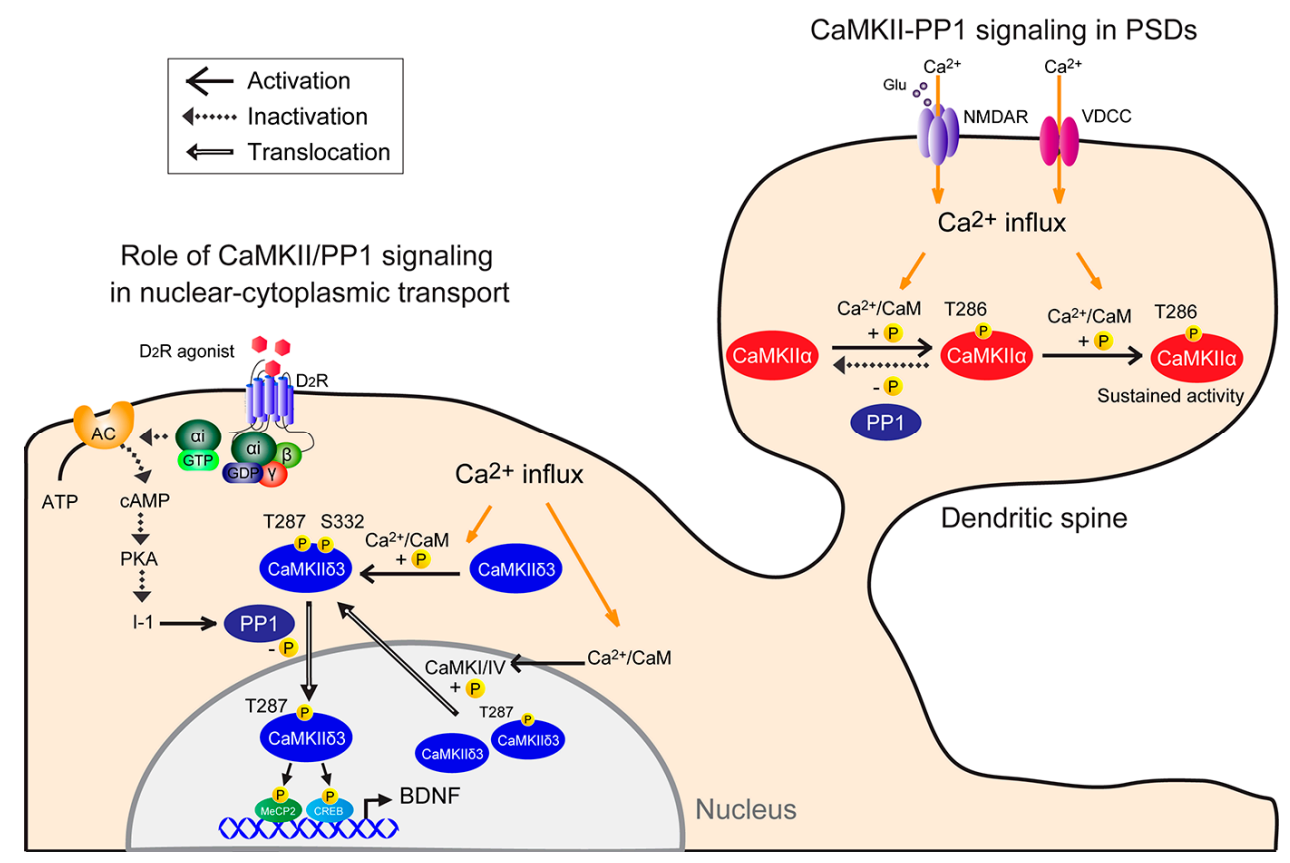

Figure 1. Model of neuronal CaMKII-PP1 signaling. (1) CaMKII-PP1 signaling in PSDs: CaMKII is simultaneously bound by $\mathrm{Ca}^{2+} / \mathrm{CaM}$ following a $\mathrm{Ca}^{2+}$ stimulus. In this condition, one subunit acts as a substrate for the other, resulting in Thr286 phosphorylation. Once that subunit is phosphorylated, subsequent phosphorylation within the holoenzyme is more likely to occur, as $\mathrm{Ca}^{2+}$ levels required for the second phosphorylation are lower than those required for the initial phosphorylation (sustained activity). Thus, CaMKII remains active, even when basal $\mathrm{Ca}^{2+}$ levels are re-established, until it is dephosphorylated by PP1. CaMKII activity is sustained if the number of phosphorylated subunits exceeds a threshold and the phosphorylation rate exceeds the dephosphorylation rate. (2) Role of CaMKII/PP1 signaling in nuclear-cytoplasmic transport: Under basal conditions, CaMKII $\delta 3$ is autonomously active in part due to spontaneous neuronal activity. Cytoplasmic CaMKII $\delta 3$ 
is autophosphorylated, and D2R-mediated PP1 activation mediates CaMKII $\delta 3$ dephosphorylation at Ser332. For example, stimulation with a dopamine D2R agonist increases PP1 activity by inactivating the cAMP/PKA/inhibitor 1 (I-1) pathway, and in turn PP1 dephosphorylates CaMKII 3 at Ser332 in the cytoplasm, enabling its nuclear translocation. Thereafter, nuclear CaMKII3 phosphorylates transcription factors, including MeCP2 and CREB, increasing BDNF expression. Depolarization causes $\mathrm{Ca}^{2+}$ entry into neurons through NMDA receptors or voltage-dependent calcium channels and promotes CaMKII $\delta 3$ autophosphorylation at Thr287 and Ser332 in the cytosol. Conversely, nuclear CaMKI or CaMKIV activity may promote CaMKII 83 nuclear export via Ser332 phosphorylation.

Acknowledgments: This work was supported by MEXT/JSPS KAKENHI Grant 25460090 (to Norifumi Shioda). Author Contributions: Norifumi Shioda and Kohji Fukunaga wrote the manuscript.

Conflicts of Interest: The authors declare no conflict of interest.

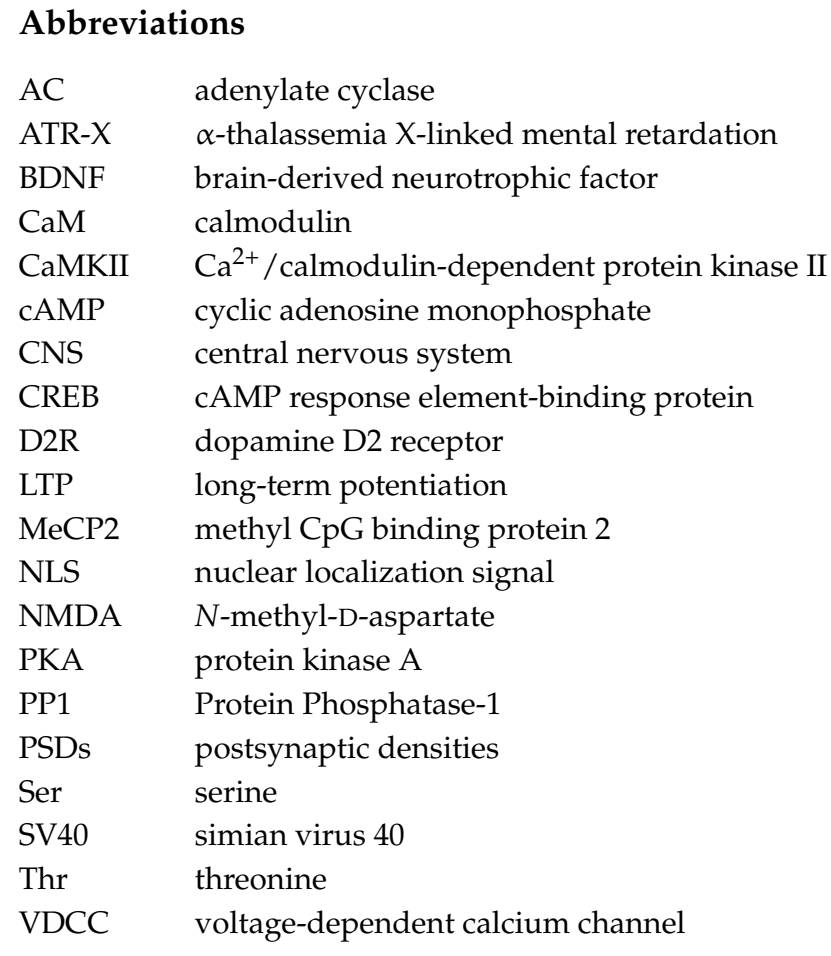

\section{References}

1. Braun, A.P.; Schulman, H. The multifunctional calcium/calmodulin-dependent protein kinase: From form to function. Annu. Rev. Physiol. 1995, 57, 417-445. [CrossRef] [PubMed]

2. Colbran, R.J.; Soderling, T.R. Calcium/calmodulin-dependent protein kinase II. Curr. Top. Cell Regul. 1990, 31, 181-221. [PubMed]

3. Fukunaga, K.; Miyamoto, E. A working model of CaM kinase II activity in hippocampal long-term potentiation and memory. Neurosci. Res. 2000, 38, 3-17. [CrossRef]

4. Schulman, H.; Hanson, P.I. Multifunctional $\mathrm{Ca}^{2+} /$ calmodulin dependent protein kinase. Neurochem. Res. 1993, 18, 65-77. [CrossRef] [PubMed]

5. Takeuchi, Y.; Yamamoto, H.; Fukunaga, K.; Miyakawa, T.; Miyamoto, E. Identification of the isoforms of $\mathrm{Ca}^{2+} /$ calmodulin-dependent protein kinase II in rat astrocytes and their subcellular localization. J. Neurochem. 2000, 74, 2558-2567. [CrossRef]

6. Lisman, J.; Yasuda, R.; Raghavachari, S. Mechanisms of CaMKII action in long-term potentiation. Nat. Rev. Neurosci. 2012, 13, 169-182. [CrossRef] [PubMed]

7. Coultrap, S.J.; Bayer, K.U. CaMKII regulation in information processing and storage. Trends Neurosci. 2012, 35, 607-618. [CrossRef] [PubMed] 
8. Hell, J.W. CaMKII: Claiming center stage in postsynaptic function and organization. Neuron 2014, 81, $249-265$. [CrossRef] [PubMed]

9. Fukunaga, K.; Stoppini, L.; Miyamoto, E.; Muller, D. Long-term potentiation is associated with an increased activity of $\mathrm{Ca}^{2+} /$ calmodulin-dependent protein kinase II. J. Biol. Chem. 1993, 268, 7863-7867. [PubMed]

10. Bliss, T.V.; Collingridge, G.L. A synaptic model of memory: Long-term potentiation in the hippocampus. Nature 1993, 361, 31-39. [CrossRef] [PubMed]

11. Kolodziej, S.J.; Hudmon, A.; Waxham, M.N.; Stoops, J.K. Three-dimensional reconstructions of calcium/calmodulin-dependent (CaM) kinase IIalpha and truncated CaM kinase IIalpha reveal a unique organization for its structural core and functional domains. J. Biol. Chem. 2000, 275, 14354-14359. [CrossRef] [PubMed]

12. Hanson, P.I.; Meyer, T.; Stryer, L.; Schulman, H. Dual role of calmodulin in autophosphorylation of multifunctional CaM kinase may underlie decoding of calcium signals. Neuron 1994, 12, 943-956. [CrossRef]

13. Miller, P.; Zhabotinsky, A.M.; Lisman, J.E.; Wang, X.J. The stability of a stochastic CaMKII switch: Dependence on the number of enzyme molecules and protein turnover. PLoS Biol. 2005, 3, e107. [CrossRef] [PubMed]

14. Brocke, L.; Srinivasan, M.; Schulman, H. Developmental and regional expression of multifunctional $\mathrm{Ca}^{2+} /$ calmodulin-dependent protein kinase isoforms in rat brain. J. Neurosci. 1995, 15, 6797-6808. [PubMed]

15. Tobimatsu, T.; Kameshita, I.; Fujisawa, H. Molecular cloning of the cDNA encoding the third polypeptide (gamma) of brain calmodulin-dependent protein kinase II. J. Biol. Chem. 1988, 263, 16082-16086. [PubMed]

16. Mayer, P.; Möhlig, M.; Schatz, H.; Pfeiffer, A. New isoforms of multifunctional calcium/calmodulindependent protein kinase II. FEBS Lett. 1993, 333, 315-318. [CrossRef]

17. Srinivasan, M.; Edman, C.F.; Schulman, H. Alternative splicing introduces a nuclear localization signal that targets multifunctional CaM kinase to the nucleus. J. Cell Biol. 1994, 126, 839-852. [CrossRef] [PubMed]

18. Edman, C.F.; Schulman, H. Identification and characterization of B-CaM kinase and C-CaM kinase from rat heart, two new multifunctional $\mathrm{Ca}^{2+} /$ calmodulin-dependent protein kinase isoforms. Biochim. Biophys. Acta 1994, 1221, 89-101. [CrossRef]

19. Heist, E.K.; Srinivasan, M.; Schulman, H. Phosphorylation at the nuclear localization signal of $\mathrm{Ca}^{2+} /$ calmodulin-dependent protein kinase II blocks its nuclear targeting. J. Biol. Chem. 1998, 273, 19763-19771. [CrossRef] [PubMed]

20. Cohen, P.T. Protein phosphatase 1: Targeted in many directions. J. Cell Sci. 2002, 115, 241-256. [PubMed]

21. Cohen, P.T. Two isoforms of protein phosphatase 1 may be produced from the same gene. FEBS Lett. 1988, 232, 17-23. [CrossRef]

22. Dombrádi, V.; Axton, J.M.; Brewis, N.D.; da Cruz e Silva, E.F.; Alphey, L.; Cohen, P.T. Drosophila contains three genes that encode distinct isoforms of protein phosphatase 1. Eur. J. Biochem. 1990, 194, 739-745. [CrossRef] [PubMed]

23. Sasaki, K.; Shima, H.; Kitagawa, Y.; Irino, S.; Sugimura, T.; Nagao, M. Identification of members of the protein phosphatase 1 gene family in the rat and enhanced expression of protein phosphatase 1alpha gene in rat hepatocellular carcinomas. Jpn. J. Cancer Res. 1990, 81, 1272-1280. [CrossRef] [PubMed]

24. Barker, H.M.; Craig, S.P.; Spurr, N.K.; Cohen, P.T. Sequence of human protein serine/threonine phosphatase 1and localization of the gene (PPP1CC) encoding it to chromosome bands 12q24.1-q24.2. Biochim. Biophys. Acta 1993, 1178, 228-233. [CrossRef]

25. Barker, H.M.; Brewis, N.D.; Street, A.J.; Spurr, N.K.; Cohen, P.T. Three genes for protein phosphatase 1 map to different human chromosomes: Sequence, expression and gene localisation of protein serine/threonine phosphatase 1beta (PPP1CB). Biochim. Biophys. Acta 1994, 1220, 212-218. [CrossRef]

26. Bordelon, J.R.; Smith, Y.; Nairn, A.C.; Colbran, R.J.; Greengard, P.; Muly, E.C. Differential localization of protein phosphatase-1alpha, beta, and gamma1 isoforms in primate prefrontal cortex. Cereb. Cortex. 2005, 15, 1928-1937. [CrossRef] [PubMed]

27. Lisman, J.E.; Zhabotinsky, A.M. Model of synaptic memory: A CaMKII/PP1 switch that potentiates transmission by organizing an AMPA receptor anchoring assembly. Neuron 2001, 31, 191-201. [CrossRef]

28. Shioda, N.; Sawai, M.; Ishizuka, Y.; Shirao, T.; Fukunaga, K. Nuclear Translocation of Calcium/Calmodulin-dependent Protein Kinase II 33 Promoted by Protein Phosphatase-1 Enhances Brain-derived Neurotrophic Factor Expression in Dopaminergic Neurons. J. Biol. Chem. 2015, 290, 21663-21675. [CrossRef] [PubMed] 
29. Sheng, M.; Hoogenraad, C.C. The postsynaptic architecture of excitatory synapses: A more quantitative view. Annu. Rev. Biochem. 2007, 76, 823-847. [CrossRef] [PubMed]

30. Cheng, D.; Hoogenraad, C.C.; Rush, J.; Ramm, E.; Schlager, M.A.; Duong, D.M.; Xu, P.; Wijayawardana, S.R.; Hanfelt, J.; Nakagawa, T.; et al. Relative and absolute quantification of postsynaptic density proteome isolated from rat forebrain and cerebellum. Mol. Cell Proteom. 2006, 5, 1158-1170. [CrossRef] [PubMed]

31. Barria, A.; Muller, D.; Derkach, V.; Griffith, L.C.; Soderling, T.R. Regulatory phosphorylation of AMPA-type glutamate receptors by CaM-KII during long-term potentiation. Science 1997, 276, 2042-2045. [CrossRef] [PubMed]

32. Ouimet, C.C.; da Cruz e Silva, E.F.; Greengard, P. The alpha and gamma 1 isoforms of protein phosphatase 1 are highly and specifically concentrated in dendritic spines. Proc. Natl. Acad. Sci. USA 1995, 92, 3396-3400. [CrossRef] [PubMed]

33. Strack, S.; Kini, S.; Ebner, F.F.; Wadzinski, B.E.; Colbran, R.J. Differential cellular and subcellular localization of protein phosphatase 1 isoforms in brain. J. Comp. Neurol. 1999, 413, 373-384. [CrossRef]

34. Blitzer, R.D.; Connor, J.H.; Brown, G.P.; Wong, T.; Shenolikar, S.; Iyengar, R.; Landau, E.M. Gating of CaMKII by cAMP-regulated protein phosphatase activity during LTP. Science 1998, 280, 1940-1942. [CrossRef] [PubMed]

35. Mullasseril, P.; Dosemeci, A.; Lisman, J.E.; Griffith, L.C. A structural mechanism for maintaining the 'on-state' of the CaMKII memory switch in the post-synaptic density. J. Neurochem. 2007, 103, 357-364. [CrossRef] [PubMed]

36. Colbran, R.J. Targeting of calcium/calmodulin-dependent protein kinase II. Biochem. J. 2004, 378, 1-16. [CrossRef] [PubMed]

37. Bollen, M.; Peti, W.; Ragusa, M.J.; Beullens, M. The extended PP1 toolkit: Designed to create specificity. Trends Biochem. Sci. 2010, 35, 450-458. [CrossRef] [PubMed]

38. Peti, W.; Nairn, A.C.; Page, R. Structural basis for protein phosphatase 1 regulation and specificity. FEBS J. 2013, 280, 596-611. [CrossRef] [PubMed]

39. Takao, K.; Okamoto, K.; Nakagawa, T.; Neve, R.L.; Nagai, T.; Miyawaki, A.; Miyawaki, A.; Hashikawa, T.; Kobayashi, S.; Hayashi, Y. Visualization of synaptic $\mathrm{Ca}^{2+} /$ calmodulin-dependent protein kinase II activity in living neurons. J. Neurosci. 2005, 25, 3107-3112. [CrossRef] [PubMed]

40. Lee, S.J.; Escobedo-Lozoya, Y.; Szatmari, E.M.; Yasuda, R. Activation of CaMKII in single dendritic spines during long-term potentiation. Nature 2009, 458, 299-304. [CrossRef] [PubMed]

41. Otmakhov, N.; Regmi, S.; Lisman, J.E. Fast Decay of CaMKII FRET Sensor Signal in Spines after LTP Induction Is Not Due to Its Dephosphorylation. PLoS ONE 2015, 10, e0130457. [CrossRef] [PubMed]

42. Picconi, B.; Gardoni, F.; Centonze, D.; Mauceri, D.; Cenci, M.A.; Bernardi, G.; Calabresi, P.; Di Luca, M. Abnormal $\mathrm{Ca}^{2+}$-calmodulin-dependent protein kinase II function mediates synaptic and motor deficits in experimental parkinsonism. J. Neurosci. 2004, 24, 5283-5291. [CrossRef] [PubMed]

43. Brown, A.M.; Deutch, A.Y.; Colbran, R.J. Dopamine depletion alters phosphorylation of striatal proteins in a model of Parkinsonism. Eur. J. Neurosci. 2005, 22, 247-256. [CrossRef] [PubMed]

44. Brown, A.M.; Baucum, A.J.; Bass, M.A.; Colbran, R.J. Association of protein phosphatase 1 gamma 1 with spinophilin suppresses phosphatase activity in a Parkinson disease model. J. Biol. Chem. 2008, 283, 14286-14294. [CrossRef] [PubMed]

45. Shioda, N.; Beppu, H.; Fukuda, T.; Li, E.; Kitajima, I.; Fukunaga, K. Aberrant calcium/calmodulin-dependent protein kinase II (CaMKII) activity is associated with abnormal dendritic spine morphology in the ATRX mutant mouse brain. J. Neurosci. 2011, 31, 346-358. [CrossRef] [PubMed]

46. Weeber, E.J.; Jiang, Y.H.; Elgersma, Y.; Varga, A.W.; Carrasquillo, Y.; Brown, S.E.; Christian, J.M.; Mirnikjoo, B.; Silva, A.; Beaudet, A.L.; Sweatt, J.D. Derangements of hippocampal calcium/calmodulin-dependent protein kinase II in a mouse model for Angelman mental retardation syndrome. J. Neurosci. 2003, 23, 2634-2644. [PubMed]

47. Bading, H. Nuclear calcium signalling in the regulation of brain function. Nat. Rev. Neurosci. 2013, 14, 593-608. [CrossRef] [PubMed]

48. Snider, W.D. Functions of the neurotrophins during nervous system development: What the knockouts are teaching us. Cell 1994, 77, 627-638. [CrossRef]

49. Lo, D.C. Neurotrophic factors and synaptic plasticity. Neuron 1995, 15, 979-981. [CrossRef] 
50. Matthews, R.P.; Guthrie, C.R.; Wailes, L.M.; Zhao, X.; Means, A.R.; McKnight, G.S. Calcium/calmodulindependent protein kinase types II and IV differentially regulate CREB-dependent gene expression. Mol. Cell. Biol. 1994, 14, 6107-6116. [CrossRef] [PubMed]

51. Sun, P.; Enslen, H.; Myung, P.S.; Maurer, R.A. Differential activation of CREB by $\mathrm{Ca}^{2+} /$ calmodulin-dependent protein kinases type II and type IV involves phosphorylation of a site that negatively regulates activity. Genes Dev. 1994, 8, 2527-2539. [CrossRef] [PubMed]

52. Zhou, Z.; Hong, E.J.; Cohen, S.; Zhao, W.N.; Ho, H.Y.; Schmidt, L.; Chen, W.G.; Lin, Y.; Savner, E.; Griffith, E.C.; et al. Brain-specific phosphorylation of MeCP2 regulates activity-dependent Bdnf transcription, dendritic growth, and spine maturation. Neuron 2006, 52, 255-269. [CrossRef] [PubMed]

53. Shimomura, A.; Ogawa, Y.; Kitani, T.; Fujisawa, H.; Hagiwara, M. Calmodulin-dependent protein kinase II potentiates transcriptional activation through activating transcription factor 1 but not cAMP response element-binding protein. J. Biol. Chem. 1996, 271, 17957-17960. [CrossRef] [PubMed]

54. Sun, P.; Lou, L.; Maurer, R.A. Regulation of activating transcription factor-1 and the cAMP response element-binding protein by $\mathrm{Ca}^{2+} /$ calmodulin-dependent protein kinases type I, II, and IV. J. Biol. Chem. 1996, 271, 3066-3073. [CrossRef] [PubMed]

55. Yano, S.; Fukunaga, K.; Takiguchi, M.; Ushio, Y.; Mori, M.; Miyamoto, E. Regulation of CCAAT/enhancer-binding protein family members by stimulation of glutamate receptors in cultured rat cortical astrocytes. J. Biol. Chem. 1996, 271, 23520-23527. [CrossRef] [PubMed]

56. Wegner, M.; Cao, Z.; Rosenfeld, M.G. Calcium-regulated phosphorylation within the leucine zipper of C/EBP. Science 1992, 256, 370-373. [CrossRef] [PubMed]

57. Misra, R.P.; Bonni, A.; Miranti, C.K.; Rivera, V.M.; Sheng, M.; Greenberg, M.E. L-type voltage-sensitive calcium channel activation stimulates gene expression by a serum response factor-dependent pathway. J. Biol. Chem. 1994, 269, 25483-25493. [PubMed]

58. Kornhauser, J.M.; Cowan, C.W.; Shaywitz, A.J.; Dolmetsch, R.E.; Griffith, E.C.; Hu, L.S.; Haddad, C.; Xia, Z.; Greenberg, M.E. CREB transcriptional activity in neurons is regulated by multiple, calcium-specific phosphorylation events. Neuron 2002, 34, 221-233. [CrossRef]

59. Gau, D.; Lemberger, T.; von Gall, C.; Kretz, O.; Le Minh, N.; Gass, P.; Schmid, W.; Schibler, U.; Korf, H.W.; Schütz, G. Phosphorylation of CREB Ser142 regulates light-induced phase shifts of the circadian clock. Neuron 2002, 34, 245-253. [CrossRef]

60. Hendrich, B.; Bird, A. Identification and characterization of a family of mammalian methyl-CpG-binding proteins. Mol. Cell. Biol. 1998, 18, 6538-6547. [CrossRef] [PubMed]

61. Cohen, S.; Gabel, H.W.; Hemberg, M.; Hutchinson, A.N.; Sadacca, L.A.; Ebert, D.H.; Harmin, D.A.; Greenberg, R.S.; Verdine, V.K.; Zhou, Z.; et al. Genome-wide activity-dependent MeCP2 phosphorylation regulates nervous system development and function. Neuron 2011, 72, 72-85. [CrossRef] [PubMed]

62. Li, H.; Zhong, X.; Chau, K.F.; Williams, E.C.; Chang, Q. Loss of activity-induced phosphorylation of MeCP2 enhances synaptogenesis, LTP, and spatial memory. Nat. Neurosci. 2011, 14, 1001-1008. [CrossRef] [PubMed]

63. Fan, W.; Li, X.; Cooper, N.G. CaMKII $\alpha$ B mediates a survival response in retinal ganglion cells subjected to a glutamate stimulus. Investig. Ophthalmol. Vis. Sci. 2007, 48, 3854-3863. [CrossRef] [PubMed]

64. Ma, H.; Groth, R.D.; Cohen, S.M.; Emery, J.F.; Li, B.; Hoedt, E.; Zhang, G.; Neubert, T.A.; Tsien, R.W. $\gamma$ CaMKII shuttles $\mathrm{Ca}^{2+} / \mathrm{CaM}$ to the nucleus to trigger CREB phosphorylation and gene expression. Cell 2014, 159, 281-294. [CrossRef] [PubMed]

65. Park, H.; Poo, M.M. Neurotrophin regulation of neural circuit development and function. Nat. Rev. Neurosci. 2013, 14, 7-23.

66. Gonzales, M.L.; LaSalle, J.M. The role of MeCP2 in brain development and neurodevelopmental disorders. Curr. Psychiatry Rep. 2010, 12, 127-134. [CrossRef] [PubMed]

67. Guy, J.; Hendrich, B.; Holmes, M.; Martin, J.E.; Bird, A. A mouse Mecp2-null mutation causes neurological symptoms that mimic Rett syndrome. Nat. Genet. 2001, 27, 322-326. [CrossRef] [PubMed]

68. Dani, V.S.; Chang, Q.; Maffei, A.; Turrigiano, G.G.; Jaenisch, R.; Nelson, S.B. Reduced cortical activity due to a shift in the balance between excitation and inhibition in a mouse model of Rett syndrome. Proc. Natl. Acad. Sci. USA 2005, 102, 12560-12565. [CrossRef] [PubMed]

69. Shahbazian, M.; Young, J.; Yuva-Paylor, L.; Spencer, C.; Antalffy, B.; Noebels, J.; Armstrong, D.; Paylor, R.; Zoghbi, H. Mice with truncated MeCP2 recapitulate many Rett syndrome features and display hyperacetylation of histone H3. Neuron 2002, 35, 243-254. [CrossRef] 
70. Chen, R.Z.; Akbarian, S.; Tudor, M.; Jaenisch, R. Deficiency of methyl-CpG-binding protein-2 in CNS neurons results in a Rett-like phenotype in mice. Nat. Genet. 2001, 27, 327-331. [CrossRef] [PubMed]

71. Kamata, A.; Takeuchi, Y.; Fukunaga, K. Identification of the isoforms of $\mathrm{Ca}^{2+} /$ calmodulin-dependent protein kinase II and expression of brain-derived neurotrophic factor mRNAs in the substantia nigra. J. Neurochem. 2006, 96, 195-203. [CrossRef] [PubMed]

72. Takeuchi, Y.; Fukunaga, K.; Miyamoto, E. Activation of nuclear $\mathrm{Ca}^{2+} /$ calmodulin-dependent protein kinase II and brain-derived neurotrophic factor gene expression by stimulation of dopamine D2 receptor in transfected NG108-15 cells. J. Neurochem. 2002, 82, 316-328. [CrossRef] [PubMed]

73. Yoshimura, R.; Hori, H.; Ikenouchi-Sugita, A.; Umene-Nakano, W.; Katsuki, A.; Hayashi, K.; Atake, K.; Tomita, M.; Nakamura, J. Aripiprazole altered plasma levels of brain-derived neurotrophic factor and catecholamine metabolites in first-episode untreated Japanese schizophrenia patients. Hum. Psychopharmacol. 2012, 27, 33-38. [CrossRef] [PubMed]

74. Mogi, M.; Togari, A.; Kondo, T.; Mizuno, Y.; Komure, O.; Kuno, S.; Ichinose, H.; Nagatsu, T. Brain-derived growth factor and nerve growth factor concentrations are decreased in the substantia nigra in Parkinson's disease. Neurosci. Lett. 1999, 270, 45-48. [CrossRef]

75. Parain, K.; Murer, M.G.; Yan, Q.; Faucheux, B.; Agid, Y.; Hirsch, E.; Raisman-Vozari, R. Reduced expression of brain-derived neurotrophic factor protein in Parkinson's disease substantia nigra. Neuroreport 1999, 10, 557-561. [CrossRef] [PubMed]

76. Hyman, C.; Hofer, M.; Barde, Y.A.; Juhasz, M.; Yancopoulos, G.D.; Squinto, S.P.; Lindsay, R.M. BDNF is a neurotrophic factor for dopaminergic neurons of the substantia nigra. Nature 1991, 350, 230-232. [CrossRef] [PubMed]

77. Murer, M.G.; Yan, Q.; Raisman-Vozari, R. Brain-derived neurotrophic factor in the control human brain, and in Alzheimer's disease and Parkinson's disease. Prog. Neurobiol. 2001, 63, 71-124. [CrossRef]

78. Woodgett, J.R.; Davison, M.T.; Cohen, P. The calmodulin-dependent glycogen synthase kinase from rabbit skeletal muscle. Purification, subunit structure and substrate specificity. Eur. J. Biochem. 1983, 136, 481-487. [CrossRef] [PubMed]

79. Brocke, L.; Chiang, L.W.; Wagner, P.D.; Schulman, H. Functional implications of the subunit composition of neuronal CaM kinase II. J. Biol. Chem. 1999, 274, 22713-22722. [CrossRef] [PubMed]

80. Hanson, P.I.; Schulman, H. Neuronal $\mathrm{Ca}^{2+} /$ calmodulin-dependent protein kinases. Annu. Rev. Biochem. 1992, 61, 559-601. [CrossRef] [PubMed]

81. Shen, K.; Teruel, M.N.; Subramanian, K.; Meyer, T. CaMKII $\beta$ functions as an F-actin targeting module that localizes CaMKII $\alpha / \beta$ heterooligomers to dendritic spines. Neuron 1998, 21, 593-606. [CrossRef] 